\title{
From K Road to iTunes: Social and cultural changes in New Zealand recorded music communities
}

Lewis Tennant

Keywords: \# recorded music \# record shops \# music retailing \# music consumers \# online music

This article explores how recent technological changes have affected the social and cultural practices of New Zealand communities that are based on recorded music. It considers the shrinking number of brick-and-mortar record shops in the wider context of discussing how now widespread Internet usage has forever changed the music producer-distributor-consumer relationship, as well as the relationship audience members have with one another. The account tracks the history of the record retail space in 20th Century New Zealand, before drawing on conversations with 30 highly-engaged music consumers in order to explore the relevance of the record shops that remain today. Participants also discuss the impact Internet access has had on New Zealand-based music aficionados. The central theme that emerges during these conversations is that though 'something' is lost with increasingly less physical community spaces to congregate, the Internet provides a potentially more inclusive and expansive platform for a greater cross-section of audience members to feel involved. 


\section{FROM TALKERIES TO TOWER: \\ MUSIC RETAILING IN 20TH CENTURY NEW ZEALAND}

In recent years brick-and-mortar record stores have fallen on hard times, with over 3000 having closed in the US for the decade through to $2008,{ }^{1}$ and $90 \%$ of recorded music retailers having closed in the UK as of $2015 .^{2}$ Over the last twenty years in New Zealand the number of specialty music stores has fallen from approximately 300 to about 30 . $^{3}$ Brick-and-mortar record shop closures are typically a result of the rise in online music retailers and streaming services, online music piracy, major recording labels trending toward backing blockbuster pop stars rather than developing and nurturing a wider range of artists' careers, and 'big box' retailers such as The Warehouse offering physical music sales for prices smaller retailers cannot compete with. Of these factors, it is Internet usage that has had the most effect on the lessening number of physical record shops and physical recordings. Since Napster was introduced in 1999, the variety and amount of music available to the public has continued to increase, as has the ability to share, stream, and download music collaboratively, often for little or no cost. ${ }^{4}$ The effects of the Internet on the recorded music industry have been relatively swift, considering that the industry's supply chain remained fairly static throughout the 20th Century.

Following Edison's 1877 demonstration of the phonograph in the US, ${ }^{5}$ sound recordings were made available to the public in stores selling any combination of musical instruments, sheet music, and radios. By the 1940s the first stores principally selling recorded music emerged, such as Colony, Commodore, and Sam Goody's in New York, and Wallich's Music City in Los Angeles. ${ }^{6}$ In New Zealand the phonograph was demonstrated 18 months after its debut in the US, with locals quick to embrace recorded sounds. ${ }^{7}$ This afforded locals a greater sense of connection to international culture. ${ }^{8}$ In 1901 a chain called Talkeries was established, specialising in selling discs and phonographs. Charles Begg \& Co followed in 1906, opening a gramophone and phonograph department in their Dunedin store, and by 1911 five Begg's stores nationwide had such departments. ${ }^{9}$ By the mid-1920s most homes owned a disc player, while HMV opened a disc pressing plant in Australia which increased the variety of titles available locally. ${ }^{10}$ Like the US, by the 1940 s there were stores primarily focussed on selling recorded music, notably HMV in Wellington, and Marbecks in Auckland. ${ }^{11}$

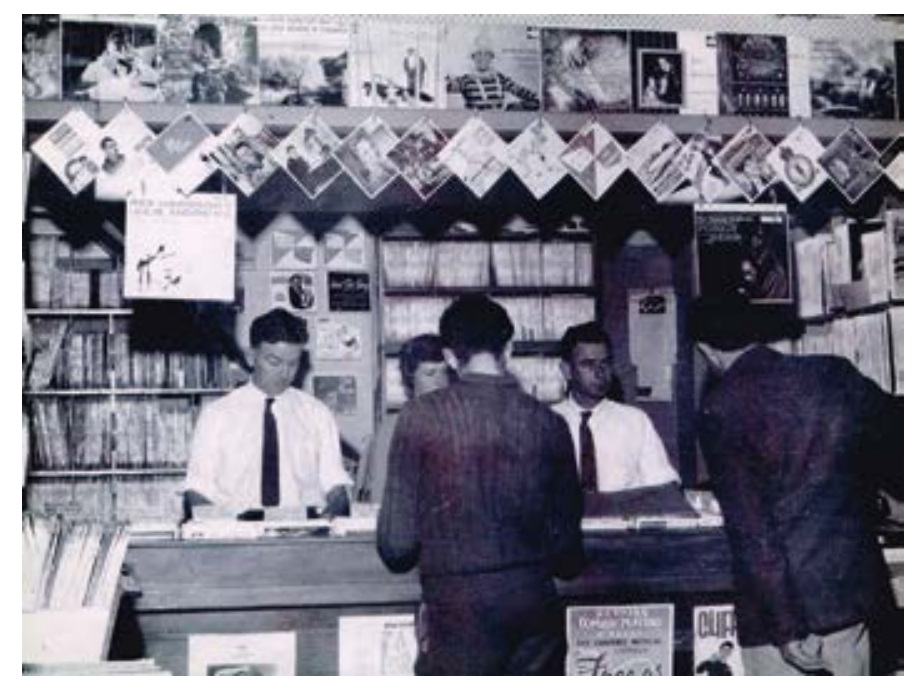

Murray \& Hayden Marbeck, c.1960 The first Marbeck Record Store was opened in 1934 by their mother and father, Eileen \& Alfred. Today, Murray's son Roger operates Arcade, Auckland. Photo courtesy of Roger Marbeck.
World War Two had two significant yet distinct effects on recorded music consumption in New Zealand. The first restricted the supply of records locally. By the 1940s the British-owned HMV/EMI controlled $90 \%$ of the music distributed in New Zealand (the result of Imperial Preference laws \& anti-trust laws), an arrangement which meant that HMV could punish local retailers for acquiring discs from other places. Supply restriction was further exacerbated by wartime rationing of aluminium and shellac (used in the production of music discs) as well as limited access to now war-sensitive shipping routes. ${ }^{12}$ The second effect of the War was that local tastes began to veer toward US music and popular culture, usurping the hitherto British Empirederived focus on music from England. American troops stationed in New Zealand had brought their culture as well as their music with them. ${ }^{13}$ In the early 1950 s the HMV/EMI monopoly was broken in time for the arrival of rock and roll near the close of the decade. Record retailers struggled to keep up with the demand for discs. By this stage the 78 $\mathrm{rpm}$ disc was being superseded by the $45 \mathrm{rpm}$ single, and sales of the latter jumped from 125,000 in the first half of 1957 , to 589,000 in the second half. In the same year imported sales dropped by two-thirds as local pressing plants were established. ${ }^{14}$

There is no formal record of the history of music retailing in New Zealand from 1965 onwards, but the trajectory followed by the industry here is comparable to what occurred in the US and the UK. In the US the 'British invasion' brought about by The Beatles in the 1960s hastened the growth of independent record stores there as demand 


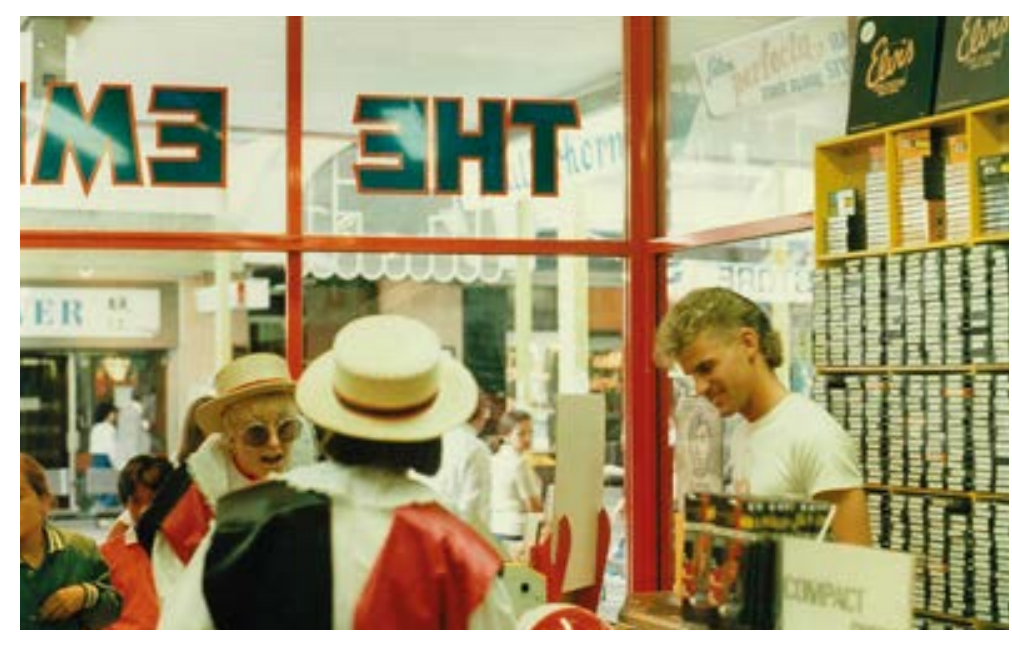

grew for sheet music and $45 \mathrm{~s}^{15}$ while in the UK stores primarily selling recorded music began to flourish from the late-1960s onwards. ${ }^{16}$ In the US, UK, and New Zealand a greater number of smaller independent stores emerged, many of which began to specialise in specific genres, and these coexisted alongside larger stores selling more general titles, as well as mail order record clubs. ${ }^{17}$

The 1970s saw even greater diversity between stores, with some known for knowledgeable staff, some for considerable back catalogue or second-hand stock, some for specific genres, and some for stocking accessories for the counter-culture such as alternative magazines or apparatus for smoking cannabis. Examples in Auckland included the Record Warehouse (which had the best singles collection in New Zealand), and Direction Records (which was the first of the alternative stores of the post-hippie era). Professor Longhairs specialised in punk and new wave, and the Record Exchange on Karangahape Road dominated the second-hand market from the mid-1970s until early into the 21 st Century.$^{18}$ As was the case in the US, corporate music retailing chains spread throughout the country from the 1980s onward, including Sounds, HMV, EMI, Tower, Tracs and The CD Store. The 1990s saw the advent of 'big box' retailers gaining discounts for bulk buying from record companies, enabling chains such as The Warehouse to offer CDs at a retail price independent stores could not realistically match. ${ }^{19}$ The turn of the Millennium heralded the rapid disintermediation of the 20th Century recording industry business model, and subsequent record shop closures.
Independent brick-and-mortar record shops have traditionally been a key intermediary between the recorded music industry and recorded music consumers. The rapid decline in the number of physical stores has led to discussions regarding the historical and ongoing social and cultural relevance of these spaces, particularly as community hubs for those who regularly frequent them. Previous studies have argued that independent brick-and-mortar stores provide lifestyle spaces that aid in fostering music-based subcultures, scenes and communities. ${ }^{20}$ Gracon (2010) described independent record shops as counter-hegemonic, stocking a wider variety of products than available from the mainstream media machine..$^{21}$ Everrett (2009) suggested independent record shops can function as educational spaces, ${ }^{22}$ Gracon (2009) further positing that music is not the only focus, in that discussions instore can extend to the wider issues of the day. He argues that in this regard there is counter-hegemony too, with these spaces often fostering alternative viewpoints to mainstream media messages. ${ }^{23}$ Mclntyre (2009) contends that independent shops can foster a sense of community for patrons and staff, encouraging social interaction between like-minded people. ${ }^{24}$ The sense of community felt in many independent shops appears to involve a collective group identity, cultivated by shared interests, language, visual symbols and ideas.

\section{FROM BRICKS TO BINARY: CHANGING MUSIC DISTRIBUTION AND CONSUMPTION PATTERNS}

The following account considers how recent technological changes have affected the social and cultural practices of recorded music communities in a New Zealand context, in turn reflecting on some of the key findings that emerged in the studies of Everret (2009), Gracon $(2009,2010)$ and Mclntrye $(2009,2011)$. These themes were explored during a series of focus groups conducted in Auckland, New Zealand. Over a two-month period in late 2014,26 people who self-identified as 'highly-engaged music consumers' each took part in one of a series of focus groups.

Owing to this study investigating changing human behaviours as a result of the recent proliferation of Internet usage, a wide range of age groups was sought. Thirteen who took part were aged in their thirties, nine were in their twenties, four in their forties, and three in 
their fifties. Six of the participants were under 25 , and though they had some memories of physical format recordings and physical format retail outlets, their primary reference point for where to procure recorded music was the Internet. However, in terms of these younger participants being skewed towards online resources, age did not always correlate with where music was primarily sourced. For example, two participants in their twenties claimed they procured over $80 \%$ of their music offline, while two participants in their 50 s stated they sourced over $99 \%$ of their music online. As engaged music consumers and fans, all participants indicated they were regular and competent Internet users. The latter point proved fruitful where the older of the participants were concerned, as all had engaged with, and had a long-term perspective on, both traditional and modern audience practices.

The data from the focus groups and one-on-one interviews was analysed using Grounded Theory ${ }^{25}$ in order to generate a set of explanations about participants initial and ongoing engagement with recorded music, what pleasures they seek when consuming music, their engagement with and reflections on changing music and communication technologies, their involvement with and perspectives on recorded music-based communities and social interactions, and finally their reflections on the ongoing social and cultural relevance of the independent brick-and-mortar record shop.

The contemporary music consumer exists in a media distribution and communication environment shaped by the substantial changes that have occurred since around the turn of the 21st century. The way participants described acquiring and consuming music, as well as interacting with other music fans, was consistent with the recent disintermediation that has occurred within the music industry. ${ }^{26}$ That is, participants described a contemporary world of choice, characterised by access to a vast amount of music and music-based information, as well as far greater potential to directly interact with other audience members globally.

In regard to accessing music, the environment participants described growing up in was limited both by geographical and industrial factors.
I spent two hours in the record section of the stationers in Howick, which was where records were sold in those days. (Si)

Yeah, we lived in Palmerston North, and I think there was one $C D$ store in the city centre and we'd only go there once a weekend. (Paz)

Despite an age difference of 27 years, Si and Paz described the same situation regarding growing up in New Zealand. The following thoughts from Vincent highlighted the industrial restrictions of this preInternet environment.

I remember growing up in Mt Manganui same thing. One record store and it was very much like a rock, Top 40 record store and, like you'd end up having to go to the Flea Markets and buy stuff or garage sales to buy like your old classics and stuff. (Vincent)

Participants were not only restricted by physical location (seemingly accentuated in 'small town' New Zealand), but by the wholesale commercial control of the supply of music globally at the time. With music availability once wholly dictated by the record company, distributor and retailer, ${ }^{27}$ these participants' options were a limited selection of titles distributed and made available in a limited number of locations. This is precisely the scarcity Anderson ${ }^{28}$ describes in his reflections on the 'Long Tail' of the modern media environment, where near unlimited selection now replaces the 'hit driven' economics that led Vincent away from his local music retailer in search of more esoteric options elsewhere.

Age 22, Eric's recent experience of going to Auckland's Rea Groovy highlighted the irreversible shift that has happened in the production, consumption, and exchange of music. ${ }^{29}$

It's one of those moments where you go to Real Groovy and you pick up the record and you are like 'wow I'm seeing it in real life!' And it costs too much. (Eric)

What was once a physical item sold at a set price is now able to be shared infinitely amongst audience members. Eric visits Real Groovy to wonder over holding a physical copy of a record and 'seeing it in real life' as he has only known an environment where recorded music is available easily on the Internet for low or no-cost. Piracy is now 
normalised, ${ }^{30}$ and many artists openly encourage accessing their music at a price determined by the consumer, and that price is often 'free'. ${ }^{31}$ It is thus unsurprising that Eric regards Real Groovy, and the trinkets it houses, as a curio.

The majority of participants used the Internet as their primary source for procuring recorded music. However, regardless of where participants procured music, most suggested brick-and-mortar record shops do maintain relevance, though only for a particular niche of audience members. These individuals appeared to frequent these spaces not because of a singular necessity to source the music in them but rather for wider social and cultural factors linked to utilising them.

I always visit, I can't help it. Even if it's in Wellington, I can't help to walk into RPM Records and have a little dig. Even Conch. I'll go there for a coffee and I'll still just find myself flicking through the bins. It's just a habit because there's always those things that I want the hard copy of, and things I've been looking for for years, those elusive bits. (Drew)

I like being able to pick up a record because you have that... you don't know before you get there that you're going to get it. And you have a feeling of like 'sweet I've found it' as opposed to just mindlessly scrolling through pages. (Bob)

The chance factor. You gotta be rewarded. It's a personal reward that nowadays is really hard to come by. Like, when you actually find that record. (Drew)

For participants who frequented physical stores, there appeared to be a sought after ritualistic aspect to record shops that cannot be replicated online. The degree of unexpectedness, physicality, and personal reward that they felt cannot be replicated digitally. Though all conceded that the Internet offers a far more extensive and instantaneous inventory of music, the chance and serendipity involved in patronising record stores, as well as the overall slower process of searching through as well as traveling to them, continued to be a beneficial and rewarding experience.

Participants' described the record store space as offering more than just a point of exchange for money and goods. Similarly, earlier studies have found that independent stores often encourage music-based subcultures, scenes and communities ${ }^{32}$ based on stocking and promoting a wider variety of products than is available from the mainstream media machine. ${ }^{33}$ However what appears markedly different at this juncture is that the fulfilments these spaces offered participants appears overwhelmingly personal rather than interpersonal. 'Digging' for records seems to place no great emphasis on the community-building aspects of shops, rather describing quite a solitary activity in a space albeit inhabited by other people.

Less than a decade after the studies of Gracon $(2009,2010)$, Mclntyre (2009), and Everett (2009), participants described enjoying many of the culturally significant aspects of independent brick-andmortar stores described in these investigations, but very little of the social. None mentioned the value of independent stores as an alternative to the mainstream media machine, ${ }^{34}$ perhaps because the internet now fulfils this role in participants' lives. Aside from Jim and Hannah, no one described independent stores as educational spaces, ${ }^{35}$ nor spaces which encourage the airing of counter-hegemonic viewpoints. ${ }^{36}$ Again, aside from Jim and Hannah, nobody cited store employees as go-to people for advice and recommendations, ${ }^{37}$ nor did they allude to any meaningful sense of group identity. ${ }^{38} \mathrm{It}$ seems widespread access to the Internet has considerably reduced the need for people to interact on any meaningful level in brick-and-mortar shops.

The apparently diminishing social draw to physical record shops might begin at the counter. Participants described a pre-Internet environment where staff members played a crucial role as both tastemakers and gatekeepers.

... in the '90s there was one store in Tauranga called The Source, and there was a guy called Chook, he used to play in a metal band called The Abyss, and he was the guy who put us onto a lot of metal at one point. (Drew)

Was that a result of this guy Chook? (Interviewer)

I guess he was that classic record store dude. You'd go to see him because (a) he was older than you and (b) he was playing in a cool band, and he'd he'd be like, 'oh you should check this out', like he kind of got to know what we were buying so when we came in the next time he'd be able to recommend something. (Drew) 
Drew's description of Chook, a record shop employee in 1990s Tauranga, New Zealand, appropriately illustrates the cultural significance of the store clerk as key tastemaker in the then limited media and information environment. The significance of a 'Chook' was not uncommon amongst particularly engaged 20th Century music consumers. However, with widespread access to the Internet in the developed world, and the disintermediation of traditional industry structures, it might be said that now any audience member might be a 'Chook' if they so wish, and their expertise need not be restricted to the small New Zealand town they reside in.

As one of a handful of participants who had themselves worked in traditional music retail, Hannah's description of being an 'expert' record shop employee was telling.

I remember there was a guy who would come in and he was really interested in the alt country scene, so he came in as a fan of Ryan Adams. A couple of us were there when he came in and he was like 'oh, what else do you think I should listen to?' And we kind of gave him all of these ideas and he ended up coming back every month or so based on... it was really based on the Border Catalogue and the Rhythm Method catalogue, but that was it. (Hannah)

Hannah's honest description of appearing an expert to the customer in question though 'it was really based on the Border Catalogue and the Rhythm Method catalogue' perfectly illustrates the restrictions in place for most audience members in the pre-Internet environment. In that more intermediated environment having access to the catalogues of record companies represented having access to different titles, and in turn being able to act as a middleperson in the consumption process. Now audience members can autonomously source, access, and consume a wide range of titles, representing the 'freed' music Hill referred to in his article on changing music consumption patterns. ${ }^{39}$ As a result, contemporary music consumers arguably have significantly less reason to call on the expertise of traditional 'gatekeepers' like the record shop employee.

A number of participants described experiencing social anxiety in physical record shops, which suggests that the Internet might provide a less intimidating platform to interact with others.
Real Groovy was one of those places when I worked there.. it was... there was a community, but there was definitely contempt in some ways [laughs]... (Jim)

I mean, record stores are some of my favourite places, and everywhere I go I try to get to a record store, at least one. But you know, they can be intimidating, and I remember record stores where you do get that Jack Black character in High Fidelity. He's a kind of composite of people... (Nasir)

Jim and Nasir both referenced the fictional book ${ }^{40}$ and subsequent film adaptation High Fidelity, ${ }^{41}$ a comedy-drama in which central character Rob Gordon owns an independent brick-and-mortar record shop staffed by Dick and Barry (the latter of whom is played by actor Jack Black). Barry is brash and obnoxious to customers who he does not feel possess the requisite knowledge of (and taste in) music required to frequent the store, often resulting in customers either being told to leave or hastily exiting of their own volition. As Jim observed as a record shop employee, and Nasir as a customer, 'Barry' is based on an employee stereotype that exists, and does not fit well with the notion that brick-and-mortar shops are inclusive spaces.

Participants' observations regarding power relations might be linked to the significance these individuals attach to music in their lives, as it seems unlikely such social anxiety would be attached to shopping for something like groceries. In the following passage, Bob's comparison of his record shop experiences with shopping online suggest that the intimidation felt by some in physical stores might be lessened by the relative anonymity the Internet accommodates.

I dunnoh if it's really related but... you asked about the benefits of online. Like I was in Real Groovy a few months ago and I bought a Chaka Khan record. This ' 80 s, you know fluoro... and the guy at the counter was like this hardcore punk and I could tell he was just having the time of his life... 'look at this guy buying this pansy ass record'. And he had it out and he was displaying it. I was like 'put it in the bag! Put it in the bag!' Maybe a little in my head... but hey, if I'd bought it online... (Bob) 
Feedback from participants also emphasised the value of what is now immediate access to music and music-based information, particularly when based in New Zealand. Whereas access to new music and music journalism was once dictated by the limits of airspeed or telephony, the Internet allows those with unrestricted connection instantaneous access to information and communication, irrespective of geographic location. ${ }^{42}$ Local audiences can now link globally to people with similar tastes with ease, encouraging a greater sense of self-identity with a customisable network of like-minded individuals. ${ }^{43}$ From the standpoint of music production, a modern incarnation of the 'Dunedin Sound' (a tag for a revered style of indie pop music created in Dunedin in the early 1980s) might now be the distinctive musical output of a global collective who convene and share ideas and files on a Facebook group page.

\section{CONTEMPROARY MUSIC COMMUNITIES: ALONE, TOGETHER?}

The following comments from Sean, Jed, Tony, and Jim encapsulate the sense of community once felt in many local independent brick-andmortar record shops.

Sean and Jed recounted interacting in-store.

You used to go to a record store and there'd be a community of people who play all different genres and listen to all different genres, you kind of mix and um... (Sean)

There was the old Real Groovy thing where there was so many people there and I'd see like [inaudible] on the other side of the room and be like 'hey here's one for you'. The old Real Groovy thing doesn't really happen and that was a massive sort of social ground... (Jed)

Back in the day with BPM and Beat Merchants you kind of had a rapport with the staff. Now there's a big turnover, and you just don't know these people. And now it is less of a sort of social outing, and they're just sort of doing the sales, you're just in a queue, there's not the same kind of amount of time and banter, and um... (Sean)

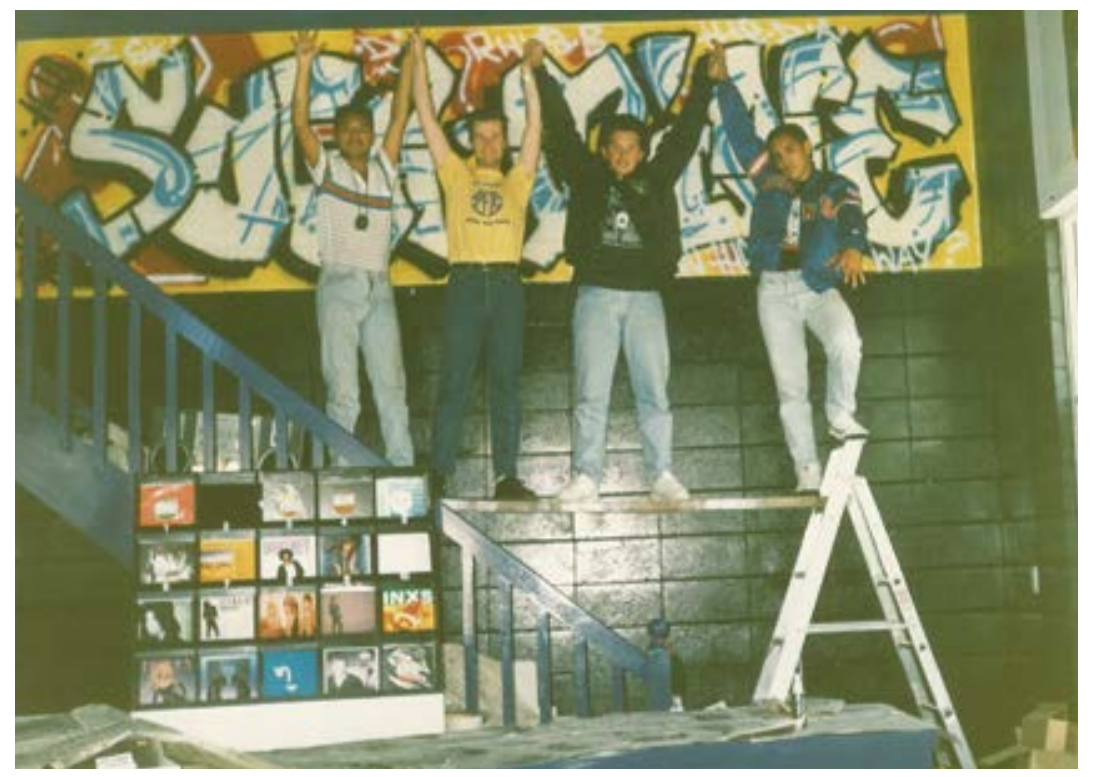

Painting the Soul Mine, Kilbirnie, Wellington, 1986

L to R. Tui Karawana (2Ski), Tony Murdoch, Rhys Bell (DJ Rhys B), and 'The Devastating Double Agent'
[On record shops in Auckland, New Zealand in the 1980s and 1990s] Had people in the music scene, you know, it wasn't just a job. They might have been musicians, deejays whatever... it seemed like a unified kind of existence. (Jim)

Participants' comments frame a community atmosphere in shops as a historical phenomenon. Sean stated 'you used to go into a record store and there'd be a community of people' and 'now it is less of a sort of social outing, and they're just sort of doing the sales, you're just in a queue, there's not the same kind of amount of time and banter', Jed referred to 'the old Real Groovy thing', Jim described working in shops in the 1980s and 1990s as not 'just a job' and a 'unified kind of existence'. These sentiments are unsurprising, considering that the Internet now accommodates many of the social facets of the brickand-mortar store environment that originally drew people to these spaces. The disintermediation that has occurred in the recorded music industry has lessened the significance of a number of middlepersons traditionally involved in the business, placing more power in the hands of artists and audience members and leaving both groups to forge a more direct relationship with each other. This might explain Sean's 
observation that many store staff are now 'just sort of doing sales' while he is 'just in a queue'.

Vincent explained how the ability to interact online had allowed him to connect globally with people with the same specific interests rather than locally with people with more diverse preferences.

I remember when a lot of us kind of jumped online mid-2000s and it straight away went to a much more global kind of reach I guess. And so instead of going and seeing the same five guys at your local record store every Saturday-who aren't into the same stuff but they kind of like tolerate it or whatever, and they talk about stuff, but it doesn't really mesh-you all of a sudden got in touch with 200 people who were all around the world who were possibly even much more focussed into your immediate interests. And so that's become really powerful. (Vincent)

Though the majority of participants agreed that physical spaces like the brick-and-mortar record shop can still yield significant social and cultural benefits, the same participants' current engagement with recorded music and fellow music fans indicated the Internet now provides these same benefits, in turn providing a seemingly more inclusive and expansive place for interaction. Participants' reflectionsfrom growing up with a reliance on one record shop and a radio, to now being able to instantly access a range of music and information on a global scale and with relative ease-tracked the transition from the 20th Century music industry model where the availability of recorded music was much more widely dictated by the record company, distributor, and retailer, ${ }^{44}$ to the modern 'post-Napster' media environment where near unlimited selection has replaced the 'hit driven' ${ }^{\prime 4}$ environment of old. Where once Tauranga's Chook guided local metal fans to new artists and albums, there are now many 'Chooks' informing people's tastes globally. For those who experience social anxiety in face-to-face situations, the Internet can provide a potentially more inclusive space. Feeling a sense of community in local record shops was discussed in an increasingly historical context, because online environments now provide many of the social benefits record stores once did. Where New Zealand's geographical isolation has often been woven into popular culture narratives-as well as narratives concerning national identityresponses in this study indicate physical location may be becoming less of a marker of identity and belonging, and less of a determinant as to how communities form around specific interests.

\section{REFERENCES}

Anderson, Chris. "Free! Why $\$ 0.00$ Is the Future of Business." 2008 http://www.wired.com/techbiz/ it/magazine/16-03/ff_free?currentPage=all.

Anderson, Chris. The Long Tail: Why the Future of Business Is Selling Less of More. New York, NY: Hachette Book Group, 2008.

Beer, David. "Social Network(Ing) Sites...Revisiting the Story So Far: A Response to Danah Boyd \& Nicole Ellison." Journal of Computer-Mediated Communication 13, no. 2 (2008): 516-29.

Bevan, $T$ (Producer), and Frears, $S$ (Director).

"High Fidelity." United States: Touchstone Pictures, 2000.

Bourke, Chris. Blue Smoke. Auckland, NZ: Auckland University Press, 2010.

Calamar, Gary, and Phil Gallo. Record Store Days: From Vinyl to Digital and Back Again. New York, NY: Sterling, 2012

Dilmperi, Athina, Tamira King, and Charles Dennis. "Pirates of the Web: The Curse of Illega Downloading." Journal of Retailing and Consum er Services 18, no. 2 (2011): 132-40.

Ediriwira, Amar. "Ladbroke Grove! The Complete Story of Record Shop Culture in Notting Hill." 2015 http://www.thevinylfactory.com/vinyl-factory-releases/record-shop-culture-notting-hill/.

Etzioni, Amitai, and Oren Etzioni. "Face-to-Face and Computer-Mediated Communities, a Comparative Analysis." The Information Society 15 no. 4 (1999): 241-48.

Everrett, Thomas M. "'Hold on to Your Genre": Digital Audio Collecting and Indie Music Connois-

Fullington, L. A. "Counter Culture: The Role and Significance of Independent Record Shops in Popular Music Culture "MPhil Diss, The University of Liverpool, 2008.

Glaser, Barney G, and Anselm L Strauss. The Discovery of Grounded Theory: Strategies for Qualitative Research. Chicago, IL: Aldine Publishing Company, 1967.

Gleeson, Clare. Meet Me at Beggs: The Story of Charles Begg \& Co, Music and Appliance Manufacturers, 1861 - 1970. Martinborough, New
Zealand: Ngaio Press, 2012.

Gracon, David. "Exiled Records and over-theCounter-Culture - a Cultural Political Economic Analysis of the Independent Record Store." PhD Diss, University of Buffalo, 2010.

Gracon, David. "The Independent Record Store as a Site of Cultural Resistance and Anti-Mcdonaldization - a Case Study of the House of Records." In The Business of Entertainment:

Popular Music, edited by R C Sickels. Westport, CT: Praeger Publishers 2009

Graham, Gary, Bernard Burnes, Gerard J. Lewis, and Janet Langer. "The Transformation of the Music Industry Supply Chain: A Major Label Perspective." International Journal of Operations \& Production Management 24, no. 11 (2004): 1087-103.

Grigg, Simon. "There's a Stack of Shellac and Vinyl / Which Is Yours Now and Which Is Mine?" 2013 http://opdiner.com/2013/theres-a-stack-of-shellac-and-vinyl-which-is-yours-now-and-which-ismine-45/\#more-623.

Hill, Brad. "The Itunes Influence, Part Two: How Apple Changed the Face of the Music Marketplace." 2013 http://www.engadget. com/2013/04/30/the-itunes-influence-part-twosetting-the-music-free/.

Hoar, Peter. "Hearing the World: Audio Technologies and Listening in New Zealand, 1879-1939." PhD thesis, The University of Auckland, 2012.

Hornby, Nick. High Fidelity. New York, NY: Riverhead Trade, 1996.

Jones, Graham. Last Shop Standing. London, England: Proper Music Publishing, 2009.

Jones, Steve. "Music That Moves You: Popular Music, Distribution and Network Technologies." Cultural Studies 16, no. 2 (2002): 213-32.

Marino, A. (Producer), and Toller, B. (Director). "I Need That Record! The Death (or Possible Survival) of the Independent Record Store." United States: Brendan Toller Productions, 2008.

McIntyre, Charles. "Diminishing Varieties of Active and Creative Retail Experience: The End of the Music Shop?". Journal of Retailing and Con- 
Morton, David. "Inventing the Dictation Machine." n.d. http://www.recording-history.org/ HTML/dicta_tech1.php.

Nuttall, Peter, Sally Arnold, Luke Carless, Lily Crockford, Katie Finnamore, Richard Frazier, and Alicia Hill. "Understanding Music Consumption through a Tribal Lens." Journal of Retailing and Consumer Services 18, no. 2 (2011): 152-59.

Ogden, James R., Denise T. Ogden, and Karl Long. "Music Marketing: A History and Landscape." Journal of Retailing and Consumer Services 18 no. 2 (2011): $120-25$.

Pettit, Emma, and Nadine Kathe Monem, eds. Old Rare New: The Independent Record Shop. London, England: Black Dog Publishing, 2008.

Rice, Craig, and Gareth Stiven. "Economic Contribution of the New Zealand Music Industry 2014 “. Auckland, New Zealand: PricewaterhouseCoopers, 2015

Rojek, Chris. Pop Music, Pop Culture. Cambridge, England: Polity Press, 2011.

Shuker, Roy. Understanding Popular Music Cul-
Simpson, Timothy A. "Streets, Sidewalks, Stores, and Stories: Narrative and Uses of Urban Spaces." Journal of Contemporory (2000): 682-716.

Staff, Bryan, and Sheran Ashley. For the Record: A History of the Recording Industry in New Zealand. Auckland, New Zealand: David Bateman Ltd, 2002 .

Taylor, R. (Producer), and Piper, P. (Director). "Last Shop Standing." United States: Conveyor, 2012.

Ward, Aleisha. "'Any Rags, Any Jazz, Any Bopper Today?" Jazz in New Zealand 1920-1955 " PhD thesis, The Univeristy of Auckland, 2012.

Wolff, C. Cleveland Rock \& Roll Memories: True and Tall Tales of the Glory Days, Told by Musicians, Djs, Promoters, \& Fans Who Made the Scene in the ' 60 s, '7os, and ' 80 s. Cleveland, $\mathrm{OH}$ : Gray \& Company, 2006.

\section{ENDNOTES}

1 Marino, A. (Producer) and Toller, B. (Director), "I Need That Record! The Death (or Possible Survival) of the Independent Record Store," (United States: Brendan Toller Productions, 2008)

2 Amar Ediriwira, "Ladbroke Grove! The Complete Story of Record Shop Culture in Notting Hill," http://www.thevinylfactory.com/ vinyl-factory-releases/record-shop-culturenotting-hill/.

3 Craig Rice and Gareth Stiven, "Economic Contribution of the New Zealand Music Industry 2014 " (Auckland, New Zealand: PricewaterhouseCoopers, 2015).

4 James R. Ogden, Denise T. Ogden, and Karl Long, "Music Marketing: A History and Landscape" Journal of Retailing and Consumer Services 18, no. 2 (2011).

5 David Morton, "Inventing the Dictation Machine," http://www.recording-history.org/ HTML/dicta_tech1.php.

6 Gary Calamar and Phil Gallo, Record Store Days: From Vinyl to Digital and Back Again (New York, NY: Sterling, 2012).

7 Chris Bourke, Blue Smoke (Auckland, NZ: Auckland University Press, 2010).

8 Peter Hoar, "Hearing the World: Audio Technologies and Listening in New Zealand, 1879-1939" (PhD thesis, The University of Auckland, 2012)

9 Clare Gleeson, Meet Me at Beggs: The Story of Charles Begg \& Co, Music and Appliance Manufacturers, 1861 - 1970 (Martinborough New Zealand: Ngaio Press, 2012).

10 Bourke.

11 lbid.

12 Aleisha Ward, "'Any Rags, Any Jazz, Any Boppers Today?" Jazz in New Zealand 1920-1955 " (PhD thesis, The Univeristy of Auckland, 2012).

13 Bryan Staff and Sheran Ashley, For the Record: A History of the Recording Industry in New Zealand (Auckland, New Zealand: David Bateman Ltd, 2002).

14 Bourke.

15 C Wolff, Cleveland Rock \& Roll Memories: True and Tall Tales of the Glory Days, Told by Musicians, Djs, Promoters, \& Fans Who Made the Scene in the '60s, '7os, and '80s (Cleveland, OH: Gray \& Company, 2006).

16 Taylor, R. (Producer) and Piper, P. (Director),
"Last Shop Standing," (United States: Conveyor, 2012)

17 Roy Shuker, Understanding Popular Music Culture, 4th ed. (Abingdon, England: Routledge, 2013).

18 Simon Grigg, "There's a Stack of Shellac and Vinyl / Which Is Yours Now and Which Is Mine?" http://opdiner.com/2013/theres-astack-of-shellac-and-vinyl-which-is-yoursnow-and-which-is-mine-45/\#more-623.

19 Gordon Campbell, "Record Shop R.I.P: A Few Seasonal Thoughts on the Demise of Ye Olde Record Store." 2010. http://werewolf. co.nz/2010/12/record-shop-r-i-p/.

20 David Gracon, "Exiled Records and overthe-Counter-Culture - a Cultural Political Economic Analysis of the Independent Record Store" (PhD Diss, University of Buffalo, 2010), Graham Jones, Lest Shop Standing (Lond England: Proper Music Publishing 2009) Gracon; Charles McIntyre, "Diminishing Varieties of Active and Creative Retail Experience: The End of the Music Shop?" Journal of Retailing and Consumer Services 16, no. 6 (2009): Thomas M. Everrett, "'Hold on to Your Genre': Digital Audio Collecting and Indie Music Connoisseurship" (MA Thesis, University of Calgary, 2007).

21 Gracon.

22 Everrett.

23 David Gracon, "The Independent Record Store as a Site of Cultural Resistance and Anti-Mcdonaldization - a Case Study of the House of Records," in The Business of Entertainment: Popular Music, ed. R C Sickels (Westport, CT: Praeger Publishers 2009).

24 Mclntyre.

25 Barney G Glaser and Anselm L Strauss, The Discovery of Grounded Theory: Strategies for Qualitative Research (Chicago, IL: Aldine Publishing Company, 1967).

26 Steve Jones, "Music That Moves You: Popular Music, Distribution and Network Technologies," Cultural Studies 16, no. 2 (2002).

27 Gary Graham et al., "The Transformation of the Music Industry Supply Chain: A Major Label Perspective," International Journal of Operations \& Production Management 24, no. 11 (2004).

28 Chris Anderson, The Long Tail: Why the Future 
of Business Is Selling Less of More (New York, NY: Hachette Book Group, 2008).

29 Chris Rojek, Pop Music, Pop Culture (Cambridge, England: Polity Press, 2011).

30 Athina Dilmperi, Tamira King, and Charles Dennis, "Pirates of the Web: The Curse of Illegal Downloading," Journal of Retailing and Consumer Services 18, no. 2 (2011): 132-40 Peter Nuttall et al., "Understanding Music Consumption through a Tribal Lens," ibid. 152-59.

31 Chris Anderson, "Free! Why $\$ 0.00$ Is the Future of Business," http://www.wired.com/techbiz/ it/magazine/16-03/ff_free?currentPage=all.

32 Gracon, "The Independent Record Store as a Site of Cultural Resistance and Anti-Mcdonaldization - a Case Study of the House of Records."; Timothy A Simpson, "Streets, Sidewalks, Stores, and Stories: Narrative and Uses of Urban Spaces," Journal of Contemporary Ethnography 29, no. 6 (2000)

33 Gracon, "Exiled Records and over-the-Counter-Culture - a Cultural Political Economic Analysis of the Independent Record Store." 34 lbid.

35 Everrett; Gracon, "The Independent Record Store as a Site of Cultural Resistance and Anti-Mcdonaldization - a Case Study of the House of Records."; "Exiled Records and overthe-Counter-Culture - a Cultural Political Economic Analysis of the Independent Record Store."; Jones; Marino and Toller; Taylor and Piper.

36 Gracon, "The Independent Record Store as a Site of Cultural Resistance and Anti-Mcdon- aldization - a Case Study of the House of Records."; "Exiled Records and over-the-Counter-Culture - a Cultural Political Economic Analysis of the Independent Record Store.": McIntyre; Everrett; Jones.

37 McIntyre; Gracon, "Exiled Records and overthe-Counter-Culture - a Cultural Political Economic Analysis of the Independent Record Store."

38 Gracon,"The Independent Record Store as a Site of Cultural Resistance and Anti-Mcdonaldization - a Case Study of the House of Records."; Simpson.

39 Brad Hill, "The Itunes Influence, Part Two: How Apple Changed the Face of the Music Marketplace "http://www.engadget. com/2013/04/30/the-itunes-influence-parttwo-setting-the-music-free/.

40 Nick Hornby, High Fidelity (New York, NY: Riverhead Trade, 1996).

41 Bevan, $\mathrm{T}$ (Producer) and Frears, S (Director) "High Fidelity," (United States: Touchstone Pictures, 2000).

42 Everrett.

43 Amitai Etzioni and Oren Etzioni, "Face-toFace and Computer-Mediated Communities, a Comparative Analysis," The Information Society 15, no. 4 (1999).

44 Graham et al.

45 Anderson. 